\title{
Changes in fetal acid base status during intravascular transfusion
}

\author{
U NICOLINI, J SANTOLAYA, N M FISK, C HUBINONT, N K KOCHENOUR, P GRECO, \\ AND C H RODECK
}

Royal Postgraduate Medical School, Institute of Obstetrics and Gynaecology, Queen Charlotte’s Maternity Hospital, London

SUMmary Umbilical venous $\mathrm{pH}, \mathrm{PCO}_{2}, \mathrm{PO}_{2}$, and base excess were measured immediately before and after 72 intravascular transfusions in 34 fetuses with erythroblastosis fetalis. In 67 uncomplicated transfusions, infused adult blood led to a mean $(95 \%$ confidence intervals) fall in $\mathrm{pH}(0 \cdot 037, \mathrm{CI}(0 \cdot 029$ to $0 \cdot 044)$ and base excess $(2 \cdot 03, \mathrm{CI} 1 \cdot 61$ to 2.45$)$ and a mean rise in $\mathrm{PCO}_{2}(0 \cdot 24 \mathrm{kPa}, \mathrm{CI} 0 \cdot 13$ to $0 \cdot 35)$. These changes correlated significantly with the increase in fetal haemoglobin and packed cell volume. Five transfusions were associated with complications within six hours: intrauterine death in two, fetal distress necessitating delivery in two, and preterm labour in one. Two had pre-existing acidosis, whereas two of the three with normal blood gas and acid base measurements before transfusion had acute changes that were outside the normal ranges that had been established in uncomplicated transfusions.

During recent years direct access to the fetal circulation has not only established a role for the intravascular transfusion of anaemic fetuses with erythroblastosis fetalis, ${ }^{1-3}$ but has also permitted closer study of the fetal environment in rhesus isoimmunisation. ${ }^{+6}$ Antenatal intravascular transfusion, whether performed fetoscopically, ${ }^{17}$ or by needling under ultrasonographic control, ${ }^{3} \times-11$ carries risk to the fetus. The total risk of the procedure is the risk of fetal blood sampling ${ }^{12}$ plus the risk of transfusion. Several reasons for fetal death after transfusion have been proposed, including changes in fetal oxygenation, and the direct cardiotoxic effects of the anticoagulant in donor blood. ${ }^{7}$

Normal ranges for fetal blood gas and acid base measurements have been described ${ }^{13}$ and used as a basis for intervention in compromised pregnancies. ${ }^{14} 15$ This study describes the normal ranges for changes in fetal blood gas and acid base measurements during uncomplicated transfusions, and assesses their use in predicting complications associated with transfusions.

\section{Methods}

Seventy two intravascular transfusions were performed for severe rhesus isoimmunisation by needling of the umbilical vein under ultrasonographic control either in the intrahepatic portion or at the placental cord insertion. Thirty four fetuses, including one set of dichorionic twins, underwent one to four procedures at intervals of two to five weeks at gestational ages of 19 to 33 weeks. The technique, volume, and rate of transfusion have been described elsewhere. ${ }^{3}$ Before transfusion, the packed cell volume and haemoglobin concentration of each fetus were determined by a Coulter S Plus counter (Coulter Electronics Ltd, Luton, England), and an additional 250-300 $\mu \mathrm{l}$ of fetal blood was aspirated into a heparinised syringe for blood gas analysis. An intravenous rather than intra-arterial position of the needle was confirmed by the direction of flow of transfused blood seen on ultrasound scan. Donor blood was adult group O, Rh negative, and seronegative for cytomegalovirus. It had been collected within the previous 24 hours, crossmatched against maternal blood, and made up to a packed cell volume of 0.65 to 0.79 . After the infusion the needle was flushed with $1 \mathrm{ml}$ of normal saline and $1 \mathrm{ml}$ of blood was aspirated and discarded. Samples for repeat haematological investigations, and a heparinised specimen for blood gas analysis were then taken. As in similar investigative studies, the additional volume of blood required was not considered to increase the risk to the fetus, ${ }^{6}$ 
especially as transfusion was replacing the aspirated volumes.

Blood gas analysis was performed within 20 minutes with an ABL 330 (Radiometer. Copenhagen, Denmark). Base excess was calculated from $\mathrm{pH}$ and $\mathrm{PCO}_{2}$ using the Thews and Harnoncourt nomogram to correct for haemoglobin concentration. Blood gas analysis was also performed on heparinised samples from nine donor packs immediately before use.

All haemoglobin concentrations before transfusion were $\geqslant 40 \mathrm{~g} / \mathrm{l}$, below which pronounced acidosis occurs. " Sixty seven transfusions in 32 fetuses were uncomplicated and the pregnancies allowed to continue. Five procedures in five singleton fetuses, however, were complicated by delivery or death of the fetus within six hours of transfusion. One of these had ascites, as did 11 of the 67 uncomplicated procedures.

Fetoplacental volume was calculated using the formula $y=22 \cdot 34+0 \cdot 44 x^{2}$ where $x$ is gestational age. ${ }^{16}$ Changes in variables after transfusion are expressed as the post-transfusion value minus the pre-transfusion value. The normal distribution of changes in blood gas measurements was confirmed with histograms. Changes within transfusions were analysed statistically by the two tailed paired Student's $t$ test, whereas comparisons between transfusions were considered as independent samples. Normal $95 \%$ data intervals were calculated from the formula: mean plus or minus $1.96 \times$ the standard deviation. Associations with haematological and obstetric data were assessed by Pearson's correlation coefficient.

\section{Results}

In 67 uncomplicated intravascular transfusions the mean $\mathrm{pH}$ and base excess fell, there was a rise in mean $\mathrm{PCO}_{2}$, but the $\mathrm{PO}_{2}$ did not change significantly (table 1). Significant, albeit weak, negative correlations were found between the changes in haematocrit and changes in $\mathrm{pH}(\mathrm{r}=-0.39 \mathrm{p}<0.01)$ and the change in base excess $(r=-0 \cdot 34, p<0 \cdot 01)$, and similarly between the changes in haemoglobin concentrations and changes in $\mathrm{pH} \quad(\mathrm{r}=-0 \cdot 34$. $p<0.01)$ and changes in base excess $(r=-0.336$, $\mathrm{p}<0 \cdot(01)$. Changes in both packed cell volumes and haemoglobin concentrations correlated positively with changes in $\mathrm{PCO}_{2}(\mathrm{r}=0.323, \mathrm{p}<0 \cdot 01$, and $r=0 \cdot 345, p<0 \cdot() 5$, respectively). There was no significant correlation of the acid base or blood gas changes with gestational age or volume transfused, except a weak positive correlation between the change in $\mathrm{PCO}_{2}$ and transfused volume expressed as a percentage of fetoplacental volume $(r=0 \cdot 260$, $\mathrm{p}<0 \cdot 05$ ).

To determine any effect of adult haemoglobin on blood gases, the changes in values in the initial transfusions (when the haemoglobin before transfusion is entirely fetal) were compared with subsequent transfusions when fetal blood may contain predominantly adult type haemoglobin (table 1). The drop in $\mathrm{pH}$ was slightly greater $(\mathrm{p}=0.045)$ during the initial transfusions, but changes in $\mathrm{PCO}_{2}$, $\mathrm{PO}_{2}$, and base excess were similar. In addition, there was no significant difference in changes in $\mathrm{pH}$, $\mathrm{PCO}_{2}, \mathrm{PO}_{2}$, or base excess between tranfusions in fetuses with pre-existing ascites and transfusions in those without ascites.

Donor blood had a mean (range) $\mathrm{pH}$ of 6.76 (6.57-6.94), $\mathrm{PCO}_{2}$ of $16 \cdot 82 \mathrm{kPa}(15 \cdot 7-17 \cdot 9)$, and $\mathrm{PO}_{2}$ of $3.96 \mathrm{kPa}(3 \cdot 25-4 \cdot 67)$.

Five transfusions were associated with complications within six hours (table 2). There were two intrauterine deaths caused by the procedure. Fetal asystole occurred immediately after the procedure in case 1, responded at first to intracardiac and intramuscular adrenaline $(0.5 \mathrm{ml}$ of $1 / 100000$ at each site), but recurred within 15 minutes. Fetal $\mathrm{pH}$ at the time of fetal cardiac injection was 6.55. Transfusions in two patients (Cases 3 and 4) were complicated by fetal distress necessitating delivery. Fetal bradycardia occurred during the procedure in case 3 and was followed by a baseline tachycardia with late decelerations. Cord $\mathrm{pH}$ at caesarean section was $7 \cdot 19$. Case 4 developed variable decelerations in the presence of normal Doppler

Table 1 Mean (95\% CI) changes in blood gas and acid/base measurements in uncomplicated transfusions for, all first, and subsequent procedures

\begin{tabular}{|c|c|c|c|}
\hline & $\begin{array}{l}\text { All procedures } \\
(n=67)\end{array}$ & $\begin{array}{l}\text { First procedures } \\
(n=27)\end{array}$ & $\begin{array}{l}\text { Subsequent procedures } \\
(n=40)\end{array}$ \\
\hline $\mathrm{pH}$ & $-\left(0.037^{*}:(-0.029\right.$ to -0.044$)$ & $-0.047 \dagger(-0.031$ to -0.061$)$ & $-0 \cdot 030 \div(-0.021$ to -0.038$)$ \\
\hline $\mathrm{PCO}_{2}$ & $0.24^{*}(0.13$ to $(0.35)$ & $0.33 \quad(0.10$ to $(0.55)$ & $0.18 \quad(0.07$ to $+(0.29)$ \\
\hline $\mathrm{PO}_{2}^{-}$ & $0.06 \quad(+0.23$ to $-(0.01)$ & $(-0.07$ to +0.65$)$ & $-0 \cdot 10 \quad(+0.06$ to $-(0.27)$ \\
\hline Base excess & $-2 \cdot 03^{*}(-1.61$ to -2.45$)$ & $-2.53 \quad(-1.71$ to -3.36$)$ & $-1.69 \quad(-1.26$ to -2.12$)$ \\
\hline
\end{tabular}

${ }^{*}=\mathrm{p}<0 .(0) 1 ; \dagger=\mathrm{p}<0.05$ (first compared with subsequent procedures). 
712 Nicolini, Santolaya, Fisk, Hubinont, Kochenour, Greco, and Rodeck

Table 2 Five procedures in which complications occurred within six hours

\begin{tabular}{|c|c|c|c|c|c|}
\hline $\begin{array}{l}\text { Case } \\
\text { No }\end{array}$ & $\begin{array}{l}\text { (iestution } \\
\text { (weeks) }\end{array}$ & $\begin{array}{l}\text { Procedure } \\
\text { No }\end{array}$ & $\begin{array}{l}\text { pH before } \\
\text { transfusion }\end{array}$ & $\begin{array}{l}\text { Complications } \\
\text { during procedure }\end{array}$ & $\begin{array}{l}\text { Complications } \\
\text { after procedure }\end{array}$ \\
\hline 1 & 26 & 2 & $7 \cdot 42$ & Bradycardia & $\begin{array}{l}\text { Intrauterine death } \\
\text { within } 15 \text { minutes }\end{array}$ \\
\hline 2 & 32 & 2 & $7 \cdot 38$ & Nonc & $\begin{array}{l}\text { Intrauterine death } \\
\text { within three hours }\end{array}$ \\
\hline 3 & 32 & 5 & $7 \cdot 37$ & $\begin{array}{l}\text { Transicnt } \\
\text { bradycardia }\end{array}$ & $\begin{array}{l}\text { Fetal distress: } \\
\text { emergency caesarean.section } \\
\text { at four hours }\end{array}$ \\
\hline 4 & 34 & 2 & $7 \cdot 24$ & None & $\begin{array}{l}\text { Variable decelerations: } \\
\text { emergency cacsarean section } \\
\text { at six hours }\end{array}$ \\
\hline 5 & 30 & 3 & $7 \cdot 20$ & None & $\begin{array}{l}\text { Ruptured membranes: } \\
\text { spontancous delivery within } \\
\text { four and a half hours }\end{array}$ \\
\hline
\end{tabular}

waveforms on testing of the umbilical artery. At 34 weeks, with borderline pre and post-transfusion $\mathrm{pH}$, and with an increase in fetal ascites after the first transfusion, the decelerations were considered adequate grounds for delivery. Case 5 had persistent hydramnios and hydrops for six weeks. Although she did not complain of contractions, her membranes ruptured and she was fully dilated within three hours of the procedure. She was considered in

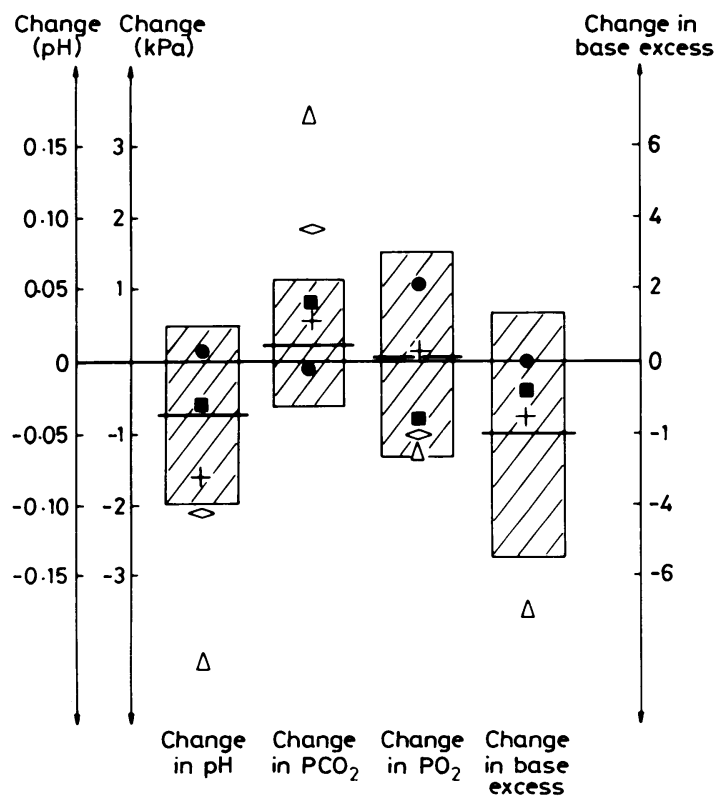

Figure Changes in $\mathrm{pH}, \mathrm{PCO}_{2}, \mathrm{PO}_{2}$, and base excess in complicated transfusions expressed against normal ranges for uncomplicated transfusions. Patient $l=\infty, 2=*, 3=\triangle$, $4=\mathbf{O}, 5=\mathbf{\square}$. In patients 4 and 5 fetal acidosis was present before transfusion started. retrospect to have been in labour at the time of transfusion, this being the probable cause of the low fetal pH measurements ( 7.20 before, and $7 \cdot 17$ after the transfusion).

The figure shows a comparison of the changes in blood gas and acid base measurements in five complicated transfusions, with normal ranges established in uncomplicated transfusions. Two of the three procedures with a normal $\mathrm{pH}$ before transfusion, were associated with abnormal changes for $\mathrm{pH}, \mathrm{PCO}_{2}$, and base excess. No result for base excess was available in case 1 because of a fault in the machine.

\section{Discussion}

Transfusion of packed cells in human fetuses produced an acute fall in $\mathrm{pH}$ and base excess, and a rise in $\mathrm{PCO}_{2}$. This drop in $\mathrm{pH}$ and base excess was the result of infusion of exogenous acids in donor blood rather than vascular spasm leading to hypoxaemia because there was no concomitant decrease in $\mathrm{PO}_{2}$.

Given the degree of acidosis in donor blood (mean pH 6.76), the changes were minor due to the buffering of acidotic donor blood during fetoplacental circulation. A suggested advantage of transfusion into the umbilical artery instead of the umbilical vein as used in this study, is that before reaching the fetus the acidotic blood is buffered and oxygenated during passage through the placental circulation. ${ }^{2}$ Lactic acid was found earlier in samples from the umbilical artery than from the umbilical vein in patients with severe rhesus disease, consistent with a substantial placental capacity for buffering. ${ }^{5}$ In this study donor blood injected into the umbilical vein must have undergone one, and presumably several, fetoplacental circulations to affect acid base measurements in fetal blood collected at the same site. To determine the relative 
buffering capacities of fetus and placenta, simultaneous samples from both umbilical artery and vein would be required after transfusion into either vessel. Such a study would pose ethical and technical difficulties.

Given the extremely high $\mathrm{PCO}_{2}$ concentrations in donor blood, the rise in $\mathrm{PCO}_{2}$ during transfusion is only small, again due to the buffering capacity of the placenta. The increase in $\mathrm{PCO}_{2}$ and the fall in base excess together determine a tendency towards mixed respiratory and metabolic acidosis.

The lack of significant change in $\mathrm{PO}_{2}$ reflects similar $\mathrm{PO}_{2} \mathrm{~s}$ in donor and fetal blood. An increase in $\mathrm{PO}_{2}$ might be expected in the presence of preexisting hypoxia. There is, however, considerable evidence that the anaemic fetus maintains adequate tissue oxygenation until the haemoglobin concentration falls below $40 \mathrm{~g} / 1^{+6}$ and in this study no haemoglobin concentration was below $40 \mathrm{~g} / \mathrm{l}$. Chronic rises in umbilical vein $\mathrm{PO}_{2}$ after transfusion have been reported in human ${ }^{17}$ and animal fetuses, ${ }^{18}{ }^{19}$ but may represent a compensatory rise in uteroplacental flow secondary to tissue hypoxia. ${ }^{17}$

The change in $\mathrm{pH}$ in first transfusions was slightly greater than in subsequent transfusions $(-0 \cdot() 47$ and $-0 \cdot 030, p=0 \cdot(045)$, but the difference in base excess was not significant. These findings are consistent with haemoglobin type having only a comparatively minor effect on blood gas and acid base measurements despite the greater affinity with oxygen of fetal compared with adult haemoglobin. ${ }^{17}$

Pre-existing fetal acidosis in two transfusions associated with complications suggested that the condition before transfusion rather than the intrauterine transfusion was responsible for delivery within six hours. In the remaining three complicated transfusions, two (cases 1 and 3 ) were associated with abnormally large changes in $\mathrm{pH}, \mathrm{PCO}_{2}$, and base excess suggesting an adverse reaction beginning during the procedure. The change in $\mathrm{PO}_{2}$, however, was within normal limits, pointing to compromise of fetoplacental perfusion rather than of placental exchange. Although both fetuses developed bradycardia during infusion this was non-specific, occurring also in several uncomplicated transfusions. Intrauterine death three hours after transfusion in the remaining patient (case 2) was unexpected and unassociated with intraoperative complications or blood gas and acid base abnormalities. Necropsy was not performed. Although intraperitoneal transfusion may cause a fetal vagal bradycardia after the procedure, none of the five in which complications developed underwent the combined procedure of intravascular transfusion followed by intraperitoneal transfusion which has become our practice in order to prolong intervals between transfusions (Nicolini et al, unpublished observations).

Acute or subacute fetal distress or death, or both. after fetal blood sampling may be due to haematoma of the cord producing tamponade, fetomaternal haemorrhage, or exsanguination into the amniotic cavity. Additional mechanisms for acute or subacute complications after transfusion are poorly understood. Mackenzie et al reviewed the possibilities and considered it unlikely that the cardiotoxic effects of citrate anticoagulant, potassium, and adenosine release from donor blood were responsible. ${ }^{7}$ The degree of acidosis in donor blood does not seem to be important. They used blood buffered to a $\mathrm{pH}$ of 7.20-7.35 and noted bradycardia during transfusion in six of 10 fetuses, eight of whom did not survive the perinatal period. This is in contrast to the paucity of complications in our series in which we used unbuffered blood.

This description of acute changes in acid base and blood gas parameters after transfusion in human fetuses permits calculation of normal ranges to predict complications directly related to the procedure. Closer postoperative monitoring of those with abnormal values who are likely to produce a live fetus may prevent fetal death by allowing timely intervention such as occurred in Case 3. We recommend the routine measurement of $\mathrm{pH}, \mathrm{PCO}_{2}$, and base excess before and after intravascular transfusion.

We thank the staff of the department of hacmatology for technical assistance. IS is supported by the Fundacion Jimence Diaz Hospital. Madrid. NMF holds a Gladys Dodds Fellowship from the Royal College of Obstetricians and Gynatecologists, and (CI has a Royal Socicty and a NATO rescarch fellowship.

\section{References}

1 Rodeck (II, Holman (A. Karnicki J. Kemp JR. Whitmore LN. Austin MA. Direct intravascular fetal blood transfusion by fetoscopy in severe rhesus isoimmunisation. Lancet 1981:i: 625-7.

- Rodeck CH. Nicolaides KII, Warsof SL. Fysh WJ. Gamsu HR. Kemp JR. The management of severe rhesus isoimmunization by fetoscopic intravascular transfusions. Am J Obstet Gynecol 1984:150:769-74.

"Nicolaides KH. Soothill PW. Rodeck CH. Clewell W. Rh discase: intravascular fetal blood transfusion by cordocentesis. Fetal Therapy 1986:1:185-92.

${ }^{+}$Nicolaides KH. Rodeck CH. Millar DS. Mibashan RS. Fetal haematology in rhesus isoimmunusation. $\mathrm{Br} \mathrm{Med} \mathrm{J} \mathrm{1985:}$ 290:661-3.

S Soothill PW, Nicolaides KH. Rodeck CH, Clewell WH. Lindridge J. Relationship of fetal hemoglobin and oxygen content to lactate concentration in $\mathrm{Rh}$ isoimmunized pregnancies. Obstet Gynecol 1987:69:268-71.

"Soothill PW. Nicolaides KH. Rodeck CH. Effect of anaemia on fetal acid-base status. Br J Obstet Grnaecol 1987:94:88()-3.

Mackenzic IZ. Bowell PJ. Ferguson J. Castle BM. Entwhistle CC. In utero intravascular transfusion of the fetus for the management of severe Rhesus isoimmunisation-at reappraisal. Br J Obstet Gynaecol 1987:94:1068-73. 
714 Nicolini, Santolaya, Fisk, Hubinont, Kochenour, Greco, and Rodeck

${ }^{\star}$ Bang J. Bock JE. Trolle D. Ultrasound guided fetal intravenous transfusion for severe rhesus haemolvtic discase. $\mathrm{Br}$ Med $J$ 1982:284:373-4

" De Crespigny LCh, Robinson HP, Quinn M. Doyle L. Ross A. Cauchi M. Ultrasound-guided fetal blood transfusion for severe Rhesus isoimmunization. Obstet Ginecol 1985;66:529-32.

1" Grannum PA. Copel JA. Plaxe SC. Scioscia AL. Hobbins JC. In utero exchange transfusion by direct intravascular injection in severe erythroblastosis fetalis. $N$ Engl J Med 1986:314:1431-4.

"Berkowitz RL. Chitkara U. Wilkins I. Lynch L. Mchalck KE. Technical aspects of intravascular intrauterine transfusions: lessons learned from thirty three procedures. Am J Obstet Gynecol 1987:157:4-9.

12 Daffos F. Capella-Pavlovsky M. Foresticr F. Fetal blood sampling during pregnancy with use of a needle guided by ultrasound: a study of 606 consecutive cases. Am J Obstet Gynecol 1985:153:655-60).

13 Soothill PW, Nicolaides KII, Rodeck CII. Campbell S. Effect of gestational age on fetal and intervillous blood gas and acid base values in human pregnancy. Fetal Therapy 1986:1:168-75.

it Nicolaides KH, Soothill PW, Rodeck CH. Campbell S. Ultrasound guided sampling of the umbilical cord and placental blood to assess fetal wellbeing. Lancet 1986:i:1065-7.
15 Pearce JM. Chamberlain GVP. Ultrasonically guided percutaneous umbilical blood sampling in the management of intrauterine growth retardation. $\mathrm{Br} J$ Obstet Gynaecol 1987:94:318-21.

16 Nicolaides KH. Clewell WH. Rodeck CH. Measurement of human fetoplacental blood volume in erythroblastosis fetalis. Am J Obstet Gynecol 1987:157:50-3.

17 Soothill PW. Nicolaides KH. Rodeck CH, Bellingham AJ. The effect of replacing fetal with adult haemaglobin on blood gas and acid/base parameters in human fetuses. Am J Obstet Gynecol 1988;158:66-9.

18 Battaglia FC. Bowes W. McGaughey HR, Makowski EL, Meschia $G$. The effect of fetal exchange transfusions with adult blood upon fetal oxygenation. Pediatr Res 1969;3:6(1-5.

19 Meschia G, Battaglia FC, Makowski EL, Droegemuller W. Effect of varying umbilical blood $\mathrm{O}_{2}$ affinity on umbilical venous pO, J Appl Physiol 1969:26:410-16.

Correspondence to Dr N Fisk. Royal Postgraduate Medical School, Institute of Obstetrics and Gynaccology, Queen Charlotte's Maternity Hospital. Goldhawk Road, London W6 (0XG.

Accepted 22 Fcbruary 1988 